\title{
Efecto de la reformulación de emulsiones sustituidas para salchichas
}

\author{
Effect of reformulation of a meat emulsion sausage type by the substitution of animal fat

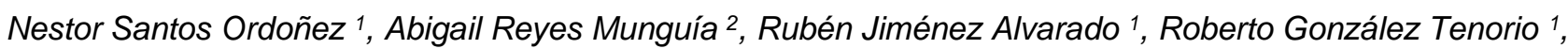 \\ Rafael G. Campos Montiel ${ }^{1}$
}

\begin{abstract}
:
The present work reports the changes in the reformulation of meat emulsions where animal fat was replaced by a multiple emulsion formulation (ME), to the different treatments (Control, reformulations with ME at 30, 20, 10 and 5\% of its formulation) were made proximal analysis to know the changes generated by the reformulation. The reformulated treatments showed an increment in nutrition and health characteristics regarding the control, mainly in the fat and protein contents $(\mathrm{p}<0.05)$. In general, the results obtained with the multiple emulsion reformulations were positive, is feasible to reformulate meat products by replacing animal fat with multiple emulsions.
\end{abstract}

\section{Keywords:}

multiple emulsion, reduction of fat content, increase of protein content, functional foods

\section{Resumen:}

El presente trabajo reporta los cambios existentes en la reformulación de emulsiones cárnicas donde se sustituyó la grasa animal por una formulación de emulsión múltiple (ME), a los diferentes tratamientos (Control, reformulaciones con ME al 30, 20, 10 y 5\% de su formulación) se les realizaron análisis proximales para conocer los cambios generados por la reformulación. Los tratamientos reformulados mostraron un incremento en sus características nutricionales y de salud respecto al control, principalmente en los contenidos de grasa y proteína $(\mathrm{p}<0.05)$. En general los resultados obtenidos en las reformulaciones con emulsión múltiple fueron positivos, por lo cual es factible la reformulación de productos cárnicos por la sustitución de grasa animal por emulsiones múltiples

Palabras Clave:

emulsión múltiple, reducción del contenido graso, aumento del contenido proteico, alimentos funcionales

\section{Introduction}

Meat products such as emulsified or coarsely ground sausage may contain up to $37 \%$ fat, these high levels have proved to be a problem for consumers prone to cardiovascular diseases or suffering from obesity (Weiss, Gibis, Schuh, \& Salminen, 2010). Currently, important changes are taking place in the eating habits of consumers, due to the emergence of scientific information that demonstrates how certain physiological functions can be modulated in the body through diet (Olmedilla-Alonso \& Jiménez-Colmenero, 2014). Foods that have been shown to improve the health and / or well-being of consumers are known as functional foods (JiménezColmenero, 2013). The attributed benefits to functional foods depend on the presence of certain beneficial components or limiting the presence of others with negative contributions (Jiménez-Colmenero, 2007). Multiple emulsions (ME) or double emulsions, are considered as an emulsion, within another emulsion, where the droplets of the dispersed phase in turn contain smaller droplets, there are mainly two types: the water-oilwater type (W/ O / W) and the oil-water-oil type (O / W /

\footnotetext{
Universidad Autónoma del Estado de Hidalgo, Instituto de Ciencias Agropecuarias nestorsantosordonez@gmail.com, ruben_jimenez@uaeh.edu.mx, abigail.reyes@uaslp.mx, rtenorio@uaeh.edu.mx,ragcamposm@gmail.com

${ }^{2}$ Universidad Autónoma de San Luis Potosí. Unidad Académica Multidisciplinaria Zona Huasteca. Romualdo del Campo No. 501, Fracc. Rafael Curiel, Ciudad Valles, S.L.P. C.P 79060.
} 
O) (McClements, 2010). This type of systems has already been used in the industry and have been shown to offer some advantages in their application in foods, such as: low caloric and fat content, flavors masking, oxidation prevention, improvement of the sensory characteristics and the encapsulation, protection and controlled release of compounds of interest (Jiménez-Colmenero, 2013). The objective of the present work was to evaluate the changes in the reformulation of sausage type meat emulsions, where animal fat was replaced by a multiple emulsion in its formulation.

\section{Materials and methods}

\section{Formulation of multiple emulsion}

The formulation was made according to Pimentel et al. (2015) with some modifications, the elaboration was carried out in 2 phases, which consisted of formulating a water-in-oil primary emulsion (xoconostle filtering and canola oil), with a mixture of hydrophilic emulsifier Panodan SDK and four parts of hydrophobic emulsifier Grindsted PGPR 90 in an Ultra Turrax IKA T25 homogenizer at 10,000 rpm for 5 minutes. In the second phase, the primary emulsion was re-emulsified in a second aqueous phase consisting of $35 \%$ whey protein isolate, homogenization was performed at 3,600 rpm for 10 minutes in an ice-water bath.

\section{Preparation of the meat emulsion}

The meat emulsion was carried out according to Cofrades et al. (2013) with some modifications. Initially, the corresponding portion of meat, salt and ice was added, homogenized in a cutter, then the animal fat or the double emulsion was added according to the corresponding formulation and they were homogenized, finally the remaining half of ice was added and they were ground, checking that the temperature did not exceed $11^{\circ} \mathrm{C}$. The meat mass was stuffed with cellulose (20 mm diameter), then cooked in hot water until its internal temperature reached $72^{\circ} \mathrm{C}$ for 30 minutes. The control treatment was performed with $20 \%$ animal fat, on the other hand, the reformulations were made with 5, 10, 20 and $30 \% \mathrm{ME}$ in its formulation replacing the animal fat.

\section{Proximate analysis}

Moisture determination: was carried out according to A.O.A.C. (1997) method 925.09, the results were expressed as a percentage.

Protein analysis: It was carried out according to the semi-micro Kjeldahl method obtained from A.O.A.C. (1997) method 957.01, the results were expressed as a percentage.

Ash evaluation: Was carried out by incineration according to A.O.A.C. (1997) method 923.03, the results were expressed as a percentage.

Determination of fat: It was carried out by means of the Soxhlet method (1993), the results were expressed as a percentage.

\section{Statistical analysis}

A completely random design was used. The results were analyzed by ANOVA, when there were significant differences $(P<0.05)$, the Tukey comparison test was used with the use of the statistical program IBM SPSS Statistics version 20 .

\section{Results:}

Table 1 shows the results obtained for proximal tests of the different treatments, in general proximal tests were affected by the type of lipid source, as well as the portion of this used in each formulation. The moisture content showed significant differences between the treatments $(P<0.05)$, the lower content was shown by the control treatment with $58.37 \%$, while the highest moisture content was found in the treatments reformulated with ME, being $5 \%$ treatment who showed the highest content of the entire test with $76.75 \%$, according to the table, in the reformulations the moisture content increased as the content of ME decreased in the formulations, this can be explained because the decrease of ME in the treatments was compensated with the addition of ice in the formulations, as well as the water contained in the ME portions added, this same effect was reported by Freire et al. (2016) where control with animal fat showed the lowest moisture content when compared to meat reformulations with ME that contained animal fat and oil of perilla as a lipid phase. The protein content showed significant differences between the treatments $(P<0.05)$, all the treatments reformulated with ME showed an increase in 
the protein content compared to the control with animal fat, this increase was proportional to the ME content, being the treatment with ME to $30 \%$ who showed the highest protein content with $23.17 \%$, while the lowest value of the whole test was shown by the control treatment with $16.82 \%$, this same effect due to the addition of ME was reported by Serdaroglu et al. (2016), who added $\mathrm{ME}$ in different percentages using 10\% sodium caseinate in its formulation, the increase in protein content in both cases can be explained by the protein sources used to make the ME. The fat content showed significant differences between the treatments $(P<0.05)$, showing positive aspects, all the treatments reformulated with ME showed a lower content of fat compared to the control, the highest percentage was found in the control treatment, which showed a $21.86 \%$ fat, the lowest content was found in the treatment with 5\% ME with $2.09 \%$, the treatment with the highest fat content within the reformulations was the treatment with $\mathrm{ME}$ at $30 \%$ with $7.81 \%$ of total fat, less than half of the content of the control, the above can be attributed to the fact that when animal fat is substituted with ME, a large part of it is composed of water and protein, which substitutes mostly animal fat, as reported by Freire et al. (2016). The ash content showed significant differences between the treatments $(P<0.05)$, the control treatment showed the lowest content with $1.94 \%$, while in the reformulations a higher content was found which increased with the ME content in the reformulations, similar as reported by Serdaroglu et al. (2016) where the treatments reformulated with $\mathrm{ME}$ showed higher ash contents compared to the control with animal fat.

Table 1: Results of the proximal analyzes of the treatments with different concentration of multiple emulsions $(5,10,20$ and $30 \%)$

\begin{tabular}{|l|l|l|l|l|}
\hline Treatments & Moisture & Protein & Fat & Cenizas \\
\hline Control & $58.37 \pm$ & $16.82 \pm$ & 21.86 & $1.94 \pm$ \\
& $.515 \mathrm{a}$ & $.063 \mathrm{a}$ & \pm & $.018 \mathrm{a}$ \\
ME 5\% & $76.75 \pm$ & $17.17 \pm$ & $.004 \mathrm{e}$ & \\
& $.308 \mathrm{~b}$ & $.119 \mathrm{~b}$ & \pm & $2.15 \pm$ \\
& & & $.093 \mathrm{a}$ & \\
ME 10\% & $73.74 \pm$ & $18.93 \pm$ & 3.98 & $2.13 \pm$ \\
& $.098 \mathrm{c}$ & $.079 \mathrm{c}$ & \pm & $.024 \mathrm{~b}$ \\
ME20\% & $68.82 \pm$ & $21.28 \pm$ & $.008 \mathrm{~b}$ & \\
& $.196 \mathrm{~d}$ & $.029 \mathrm{~d}$ & \pm & $2.24 \pm$ \\
& & & $.109 \mathrm{c}$ & \\
ME 30\% & $65.25 \pm$ & $23.17 \pm$ & 7.81 & $2.38 \pm$ \\
& $.505 \mathrm{e}$ & $.084 \mathrm{e}$ & \pm & $.017 \mathrm{~d}$ \\
& & & $.069 \mathrm{~d}$ & \\
\hline
\end{tabular}

The results are expressed as a percentage \pm standard deviation, the different letters ${ }^{a, b, c}$ express significant differences $(P<0.05)$ between the treatments in the columns.

\section{Conclusions:}

The changes obtained in the reformulations of meat emulsions with ME were positive with respect to the control, reformulations with ME showed a higher moisture content, a better protein content, as well as a reduction in the fat content, finally a higher ash content. These good results establish the basis for the development of a functional meat product.

\section{References}

AOAC. Official Methods of Analysis of the Association of Official Analytical Chemist International. Method 925.09. 1997.

AOCS. Official Methods and Recommended Practices of the American oil chemists' society. 4th Ed. Champaign. 1993.

AOAC. Official Methods of Analysis of the Association of Official Analytical Chemist International. Method 923.03. 1997.

Cofrades, S., Antoniou, I., Solas, M. T., Herrero, A. M., \& JiménezColmenero, F. (2013). Preparation and impact of multiple (water-in-oilin-water) emulsions in meat systems. Food Chemistry, 141(1), 338-346. doi: https://doi.org/10.1016/j.foodchem.2013.02.097

D.J., P. G., M.E., A. G., G., A. Á., R., S. H., J.C., G. A., \& R.G., C. M. (2015). The Process and Maturation Stability of Chihuahua Cheese with Antioxidants in Multiple Emulsions. Journal of Food Processing and Preservation, 39(6), 1027-1035. doi: doi:10.1111/jfpp.12317

Freire, M., Bou, R., Cofrades, S., Solas, M. T., \& Jimenez-Colmenero, F. (2016). Double emulsions to improve frankfurter lipid content: impact of perilla oil and pork backfat. J Sci Food Agric, 96(3), 900-908. doi: $10.1002 /$ jsfa.7163

McClements, D. J. (2010). Emulsion design to improve the delivery of functional lipophilic components. Annu Rev Food Sci Technol, 1, 241 269. doi: 10.1146/annurev.food.080708.100722. 
Jiménez-Colmenero, F. (2007). Healthier lipid formulation approaches in meat-based functional foods. Technological options for replacement of meat fats by non-meat fats. Trends in Food Science \& Technology, 18(11), 567-578. doi: https://doi.org/10.1016/j.tifs.2007.05.006

Jiménez-Colmenero, F. (2013). Potential applications of multiple emulsions in the development of healthy and functional foods. Food Research $\begin{array}{lll}\text { International, 52(1), 64-74. } & \text { doi: }\end{array}$ https://doi.org/10.1016/j.foodres.2013.02.040

Olmedilla-Alonso, B., \& Jiménez-Colmenero, F. (2014). Alimentos cárnicos funcionales: desarrollo y evaluación de sus propiedades saludables. Nutrición Hospitalaria, 29, 1197-1209.

Serdaroglu, M., Ozturk, B., \& Urgu, M. (2016). Emulsion characteristics, chemical and textural properties of meat systems produced with double emulsions as beef fat replacers. Meat Sci, 117, 187-195. doi: 10.1016/j.meatsci.2016.03.012

Weiss, J., Gibis, M., Schuh, V., \& Salminen, H. (2010). Advances in ingredient and processing systems for meat and meat products. Meat Sci, 86(1), 196-213. doi: 10.1016/j.meatsci.2010.05.008 